\title{
JUDIT, ORGOVÁNYI-GAJDOS
}

\section{AN ANALYSIS OF A TEACHERS' PROBLEM-SOLVING ENHANCEMENT PROGRAMME COMPARING NOVICE AND EXPERT TEACHERS' EXPERIENCES}

\begin{abstract}
This paper examines the results of a comparative study of teachers' experiences and opinions of problem solving thinking techniques examined in a newly developed training programme: Training Programme for Teachers' Professional Development on Problem Solving. The main aim of this Programme is to help teachers become adaptive problem solvers in classroom situations. The development process took place at the Eszterházy Károly University (Hungary) between 2014-2017 during design-based research. The final evaluation of the Programme involved ten one-day seminars with a total of 159 teachers. The measuring method evaluation was a questionnaire containing scaled, select one from a choice of answers and open-ended questions. The evaluation phase was suitable for mapping the participants' satisfactions and attitudes towards the structure, content and usefulness of the Training Programme. The sample was divided into five additional sub-samples based on participants' teaching experience for the purpose of a comparative study. The analysis of the variables in the sub-sample has demonstrated that the education programme has been found to be effective for all stages of teachers' career. In addition, the summative investigation as well as the extended earlier research supported the differences of novice and expert teachers' problem solving thinking.
\end{abstract}

\section{Introduction}

Management of school situations is an essential everyday part of the teaching profession. It could be said that the whole teaching-learning process is seen as a problem-solving and a series of decisions (Shavelson, 1973, Calderhead, 1993). Therefore, the level of teachers' practical knowledge is a key element of successful problem solving process. Practical knowledge is a practiceorientated, domain-specific, tacit and implicit concept (Munby, Russell \& Martin, 2001, Korthagen, 1993). It is a complex phenomenon that "...refers broadly to the knowledge teachers have of classroom situations and the practical dilemmas they face in carrying out purposeful action in these settings." (Carter, 1990, p. 299). So it contains "...all domains of professional insights relevant to teaching, and is 
Judit, Orgoványi-Gajdos

organised in intertwined and interconnected ways related to teaching problems." (Van Velzen et al., 2012, p. 24). Pedagogical problems can refer to any teaching tasks (planning, evaluating etc.), or any phenomenon in the teaching-learning process (group management, using different teaching-learning methods, new technology, handling diversity, managing the teaching of students with special educational needs, conflicts between students, learning materials, etc.). (Copeland et al., 1993)

New teachers are likely to face many unexpected, unusual situations in their pedagogical practice due to the lack of practical knowledge. Former research points out that they usually do not recognise complex classroom situations and that is why many new teachers look for situation-specific and short-term solutions (Peterson \& Comeaux ,1987, Borko \& Livingstone, 1989, Brown \& Mclntyre, 1993, Westerman, 1991, Hogen \& Rabinowitz, 2009, Tsui, 2009). Novices also tend to plan for the short-term and they follow the curriculum closely without paying attention to student needs or the learning environment.

Classroom management is the main difficulty novice teachers have to face because they struggle to see the relationship between class management, student behaviour, and lesson planning. Therefore they mainly make superficial, shortterm decisions aiming at the surface of problems which leads to the reoccurrence of problematic situations. (Kagan, 1992, Tann, 1994). Veenman, 1984, Melnick \& Meister, 2008). This process continues until the novice teacher becomes an expert through experience, development of practical knowledge and problem solving.

Psychological researches and educational studies of teachers' professional development had a huge effect on the theories of the development of teacher expertise. They have demonstrated that expert teachers are better problem solvers as they have a high level and well-integrated knowledge, and their schemasystem is more sophisticated with a range of scripts and routines related to pedagogic situations to draw on. They also have more analytical and interpretive skills than the novices do, so they are able to notice the deep structures of situations and find appropriate solution for them (Eysenck \& Keane, 2010, Tsui, 2009, Berliner 1988, 2004).

The literature distinguishes two types of expertise: classical (routine) and adaptive (innovative) (Eysenck \& Keane, 2010). The classical has the ability to address well defined, familiar problems in a productive way. It is based on the schema-theoretic approach to the common experiences of events (Carter \& Doyle, 1987, Carter, 1990). Behind of this routine there is a type of knowledge can be operated usefully in the same context, with the same situational features. This cognitive process is therefore mobilized by reproduction and experiments of trial and error (Glaser, 1991). Adaptive (innovative) experts have more flexible cognitive structures. They are able to address unknown or ill-defined problems by quickly recognising ineffective solutions and thinking about innovative ways of dealing with problems (Hatano \& Inagaki, 1986, Bransford et al., 2000, Eysenck \& Keane, 2010). Pedagogical situations often cover complex and atypical problems that need adaptive expertise to solve them. 
Concerning the student teachers, it is useful to cite Silverman: "Students must have the opportunity to bridge the gap between theory and practice. To do this, they must be encouraged to become thoughtful, creative problem solvers. Students need practice in analysing problems, asking important questions, considering various responses, arguing for or against different solutions, and seeking more than one answer to a problem. To become successful teachers, they will need to learn to think through problems so that they can arrive at effective solutions" (Silverman, 1990, p. 95). As far as experts are concerned educational researchers claim that "teaching is increasingly seen as a professional activity requiring a careful analysis of each situation, choice of objectives, development and monitoring of suitable learning opportunities, evaluation of their impact on students' achievement, responsiveness to students' learning needs and a personal or collective reflection on the whole process. As professionals, teachers are expected to act as researchers and problem solvers, reflecting on their own practice and assuming greater responsibility for their own professional development." (OECD, 2005, p. 99)

As a result of a design-based research at the Eszterházy Károly University (Hungary), the Training Programme for Teachers' Professional Development on Problem Solving has been developed for teachers (Orgoványi-Gajdos, 2016). This study presents the results of the summative evaluation of the training programme and it highlights the differences between novice and expert teachers' opinions and attitudes.

\section{Main features of the Training Programme for Teachers' Professional Development on Problem Solving}

\subsection{Theoretical background of the Programme}

In order to be able to solve pedagogical problems, teachers need to develop their professional practical knowledge by conscious and continuous reflection. The Training Programme for Teachers' Professional Development on Problem Solving offers thinking frames and techniques for self-case reflection. This is a special metacognitive process aimed at solving individual pedagogical situations (Orgoványi-Gajdos, 2016). It is based on de Bono's (1996) five-step problemsolving model including 1. Problem and goal setting, 2. Collecting information, 3. Developing alternatives, 4. Decision making, 5. Acting. The training contains thinking tools and methods for each step to help teachers' reflective process. During the training, participants deal with their own pedagogical cases they had brought from their real school experiences.

The main aim of this programme is to help teachers become adaptive experts who:

- are able to transfer their theoretical knowledge into practice and to move from reproductive thinking to a more productive and adaptive one,

- are able to see their challenges as part of a system and consciously follow one's cognitive process from perception to the solution of their own individual problems, 
- are able to define the problem itself, to set the goal and recognize one's own role in it,

- are able to collect, divide, analyse and categorise subject (opinion, impression, feelings) and object (facts) information in a given situation and are able to see and ask questions about the missing elements,

- are able to find the possible sources of the problems by discovering the relationship between cause and effect,

- are able to generate alternatives by collecting existing solutions (methods, partnership with professionals) and by developing new ways with creative thinking techniques,

- are able to evaluate the alternatives, choose between them and justify the decision. (Orgoványi-Gajdos, 2016)

\subsection{The structure of the Programme}

The whole training programme can be found in the book called Teachers' Professional Development on Problem Solving - Theory and practice for Teachers and Teacher Educators (see Orgoványi-Gajdos, 2016).

This study focusing the main results of the evaluation of the shortened training programme so it is necessary to give a summary of its structure.

The shortened version is a one-day training (including 8 hours with brakes). This version consists of three parts: The first is the introductory phase and it is also aimed at revealing participants' prior knowledge ( 2 hours). The second is the main part when participants meet the five-step model of problem solving process and its special techniques (5 hours). The final part of the programme includes a reflective, an evaluating and a closing process (1 hours).

The main part is based on the five-step problem-solving model and the given techniques (1. table).

\begin{tabular}{|c|c|}
\hline Steps of the problem solving process & Used thinking tools \\
\hline 1. Problem and goal setting & Defining the aim (de Bono 1996) \\
\hline \multirow[t]{2}{*}{ 2. Collecting information } & Objective and subjective information \\
\hline & Fishbone diagram (Ishikawa 1982) \\
\hline 3. Developing alternatives & SCRAMPER (Eberle 1971) \\
\hline \multirow[t]{2}{*}{ 4. Decision making } & Future Wheel (Glenn 1972) \\
\hline & Force-field analysis (Lewin 1947) \\
\hline 5. Acting & Starbursting (Tague 2005) \\
\hline
\end{tabular}

1. table: Thinking tools used by the Training Program for Teachers' Professional Development on Problem Solving (Orgoványi-Gajdo,s 2016)

1. Problem and goal setting: In this part participants can see how perception can affect problem posing and goal setting. At the beginning of the exercise 
participants choose a current pedagogic challenge. Having set the problem, it is necessary to state and clarify the goal (1. Figure). It delays solvers' intention and the purpose as well. It is important to emphasise that if the goal is precisely defined, one has better chance to solve the problem successfully. When the participants are finished, they can discuss their thoughts directed by the facilitators.
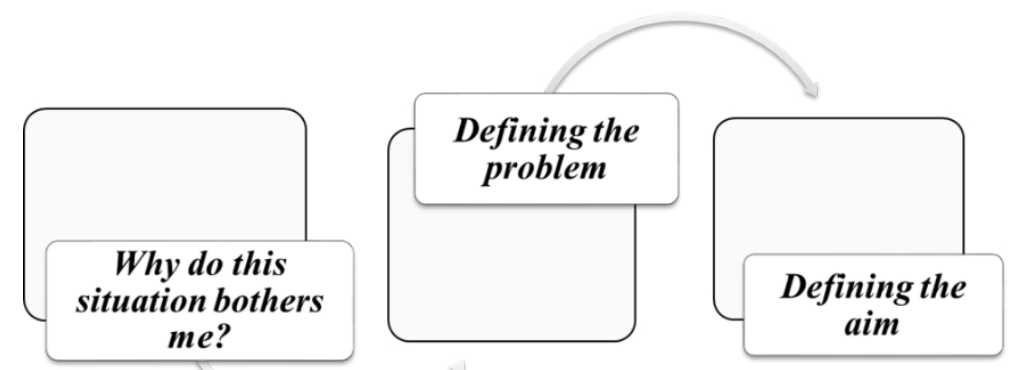

1. Figure Defining the aim (source: Orgoványi-Gajdos 2016, p. 62)

2. Collecting information: This step concentrates on the connection among the different types of information. The techniques employed help teachers to look behind the scenes, separate the different information from each other's, as well as see the relationship between cause and effect. When teachers speak about their problematic situation, they do not usually realize the facts, the opinions or the impressions. They tend to handle these elements without any distinction: for example, they frequently handle an opinion as a fact. It is also important to consider where the information comes from.

\begin{tabular}{|l|l|l|}
\hline \multicolumn{2}{|c|}{ Objective information } \\
\hline Fact & The fact I know .... & $\begin{array}{l}\text { From where and from whom do I } \\
\text { collect this information? }\end{array}$ \\
\hline Clarified issues & $\begin{array}{l}\text { What I do not know ... What kind } \\
\text { of information do I need? }\end{array}$ & From where I will get them? \\
\hline
\end{tabular}

\begin{tabular}{|l|l|l|l|}
\hline \multicolumn{3}{|c|}{ Subjective information } \\
\hline $\begin{array}{l}\text { Feelings } \\
\text { Emotions }\end{array}$ & Involved person & His/her feeling & Why do I think it? \\
\hline $\begin{array}{l}\text { Opinion } \\
\text { Assumption } \\
\text { Impression }\end{array}$ & Who? & $\begin{array}{l}\text { What does he or she } \\
\text { think? }\end{array}$ & How do I know it? \\
\hline
\end{tabular}

2. table: Source material for dividing objective and subjective information (source:

Orgoványi-Gajdos 2016, p. 70) 
The exercise of objective and subjective information enables participants to divide the objective and the subjective aspects of the situations and to see the different quality and the level of the information clearly (2. table). After filling the tables participants can discuss how their thinking process about their situation developed and what was the most benefit of exercise.

The Fishbone diagram (or Ishakawa diagram) was created by Kaoru Ishikawa in the 60's. (Ishikawa, 1982, Tague, 2005). It has a horizontal arrow, which is the body of the fish picture and ends with the problem focus which is placed on the head of the fish. From this arrow, some diagonal lines rise completing the bones of the fish. These bones symbolize the possible categories of the causes of the situation. The main bones can be divided into smaller bones that symbolize the sub-causes (2. Figure). It helps teachers to take a look at a possible relationship between cause and effect by using categories (such as people, methods, process, materials, environment) and by identifying the origin of a particular situation. During the exercise group members fill in the diagram related to the situation they deal with. First, they identify the problem and then they can ask the following question: Why does/did it happen? They can get deeper and deeper if they can ask the question again and again for themselves (Tague, 2005). After finishing the picture, the group can discuss what kind of experiences and new pieces of information they got by completing the diagram.

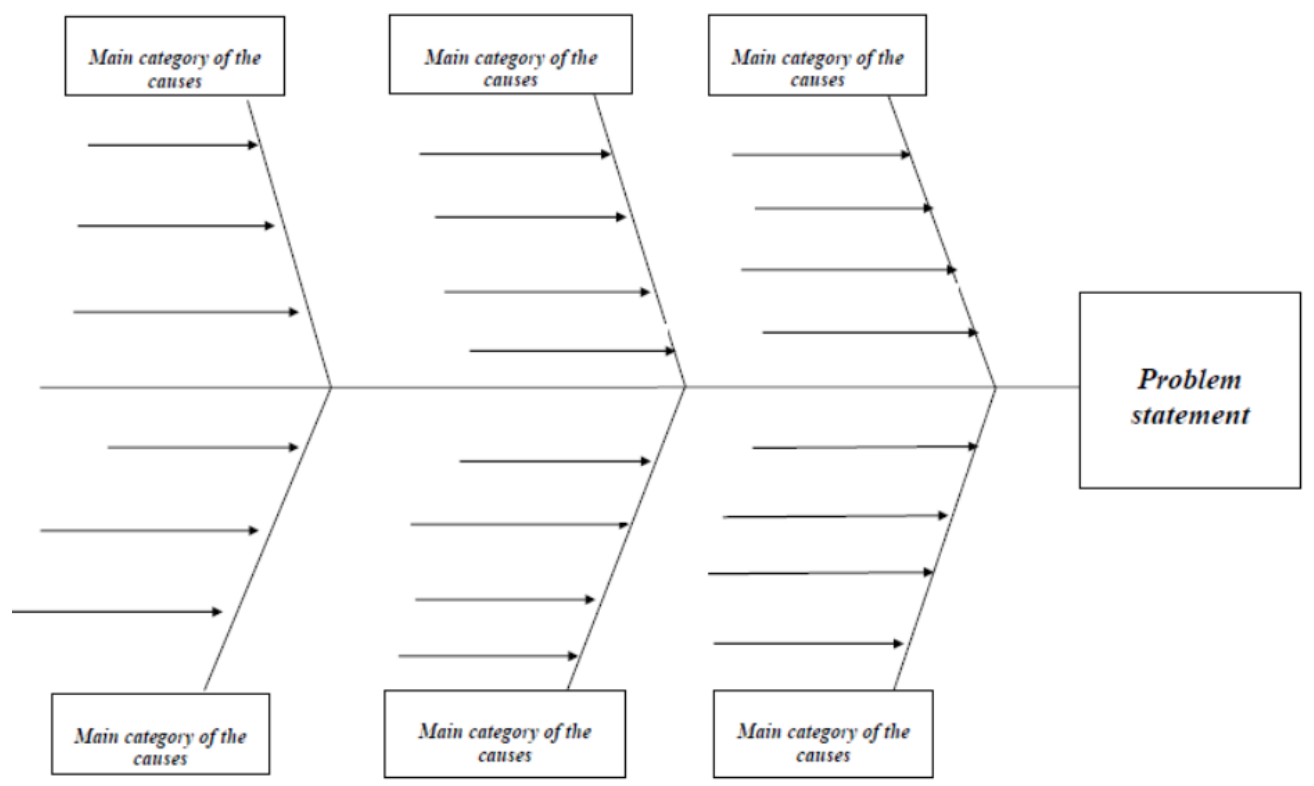

2. Figure Fishbone diagram (source: Orgoványi-Gajdos 2016, 66)

3. Developing alternatives: The aim of this step is to collect as many alternatives as possible by coming up with new ways and forms of solution. The so-called 
SCAMPER method (Eberle, 1971) supports divergent or creative thinking. It is an acronym that includes the next cognitive processes: Substitute, Combine, Adapt, Magnify, Put to other uses, Eliminate, Rearrange. The aim of these cognitive operations is to let the person change his/her view and take other perspectives of the challenging pedagogical situations. After filling the table participants can discuss which cognitive operation was the most benefit and what kind of alternatives had been developed (3. table).

\begin{tabular}{|c|c|c|}
\hline $\begin{array}{l}\text { Cognitive } \\
\text { process }\end{array}$ & Helpful questions & Own ideas \\
\hline Substitute & $\begin{array}{l}\text { What will happen if I change the } \\
\text { materials, the involved persons, } \\
\text { methods, environment, feelings or } \\
\text { the process of the situation in my } \\
\text { thought? }\end{array}$ & \\
\hline Combine & $\begin{array}{l}\text { What kind of new ideas turn up if I } \\
\text { mix some parts of the situation in } \\
\text { my thought? }\end{array}$ & \\
\hline Adapt & $\begin{array}{l}\text { Do I know any similar situation, } \\
\text { context, materials etc. I can use for } \\
\text { creating my solution? }\end{array}$ & \\
\hline Modify & $\begin{array}{l}\text { Are there any new ideas turning up } \\
\text { when l extend or decrease some } \\
\text { components of the situation in my } \\
\text { mind? }\end{array}$ & \\
\hline $\begin{array}{c}\text { Put to another } \\
\text { use }\end{array}$ & $\begin{array}{l}\text { What will happen if I use } \\
\text { a material, tool, method } \\
\text { completely differently than before? }\end{array}$ & \\
\hline Eliminate & $\begin{array}{l}\text { What are the least important } \\
\text { factors of the situation? What } \\
\text { happens if I eliminate some } \\
\text { features, parts or factors of the } \\
\text { situation? }\end{array}$ & \\
\hline Rearrange & $\begin{array}{l}\text { What will happen if I turn the } \\
\text { situation upside down in my mind } \\
\text { or if I move from the end to the } \\
\text { beginning of the situation? What } \\
\text { will happen if I reorganize the } \\
\text { main component of the situation? }\end{array}$ & \\
\hline
\end{tabular}

3. table: SCAMPER method (source: Orgoványi-Gajdos 2016, 82)

4. Decision making: Decision is the final step of the problem solving thinking process before the interaction phase. All of the mentioned and analysed aspects and factors of the case are considered in this phase. The techniques used in this 
phase can help participants to rank the possible solutions and define the priority steps. Future Wheel (or effects wheel) is a graphic tool for organizing thinking about future possibilities by defining primary, secondary and tertiary outcomes of a situation (Glenn, 1972). This tool helps participants to consider the possible future consequences of a solution as well as predict and realize the most possible and the worst possible (or most dangerous) future actions. Force-field analysis was originally developed for group decision by Kurt Lewin (1947). This technique helps to analyse forces for and against a change or a solution. However, it does not only indicate the advantage of the solution but also draws the attention to those possible risks that one should face when he/she chooses this solution. During the discussions, participants can share their findings, experiences, and opinions related to the task.

5. Acting: After choosing the best solution, the next step is to plan the implementation of the decision. Teachers certainly know how important the role of planning is in the teaching-learning process. During planning, the solvers can consider what, where, when and how they will exactly perform and what kind of tools or supports they needs (see Starbursting method: Tague, 2005).

\section{Research strategy and methods}

This study was based on a design-based research. The most important features of this kind of research can be summarized as follows: pragmatic, interventionist, grounded, iterative, includes the involvement of practitioners, process orientated, utility orientated, theory orientated (Van den Akker, 2007, Hogue, 2013). The research strategy basically included a mixed-method: qualitative and quantitative paradigms changed each other (Creswell \& Plano, 2011). The paper does not go into details of the design, it shows only the relevant aspect of the process.

The development process had three main phases and took place at Eszterházy Károly University (Hungary) between 2015-2017. During the preparatory phase of the research, I examined and synthesized the national and international literature on the subject. The aim of the development phase was to create an educational programme which focused on the improvement of teachers' problem-solving thinking skills. At the end of this phase a 20 hour problem-solving pilot Training Programme was developed and tested. (Orgoványi-Gajdos, 2016).

The summative evaluation phase was based on a shortened, one-day version of the Training Programme that contains 8 training hours. It includes all the techniques relevant to the problem-solving process and to which the study was directed. The aim of the evaluation process was to collect data regarding the participants' opinions, satisfaction, and attitudes towards the structure, content and usefulness of the Programme and its techniques. For the purpose of a comparative study the sample was divided into five additional sub-samples based on the participants' teaching experience. The focus of the comparative 
analysis was to examine the relationship between the number of years spent in teaching and the variables being studied (structure, content, usefulness and efficiency of the education programme).

The main research questions of the comparative study:

- What are the teachers' opinions of the main features of the Training Programme?

- What do teachers recognize as the main impact of the Training Programme?

- Are there any differences in the opinions and attitudes towards the problem solving model and its techniques between novice and expert teachers?

The research method of this evaluation phase was a questionnaire with the variety of question types: open-ended questions, Likert-scale, and one-choice questions. The open-ended questions were content analysed by an open coding process of the answers. The reliability of the categories was tested by intercoding (see Krippendorff, 2004). The scaled questions focused on the participants' opinions concerning the aim, the structure and the content of the programme. One-choice questions referred to the methods and techniques. The data was analysed by descriptive (frequencies, crosstab analysis) and mathematical (correlations, regressions) statistics.

\section{Sampling}

The data collection process included ten (eight-hours long) training courses with different participants between the spring of 2015 and the spring of 2016 at Eszterházy Károly University (Hungary). During this research period all the participants took part in initial teacher education programme relating one or more MA major in the university to gain either the first or an additional teacher qualification. The ten training groups were mixed groups. The participants' teaching experience were between zero and 33 years. Some of the participants taught in ISCD 1 level (9\%), in ISCD 2 level (19\%) or in both (23\%). The others worked in secondary school (ISCD 3) (27\%). $9 \%$ of the participant taught in every mentioned level. 13\% of the participants had no teaching experience. Therefore, the ten groups were diverse in the participants' professional background and teaching experiences (4. table). A total of 159 students participated in these courses. For the purpose of a comparative study, during the data-analysing process the sample was divided into five additional sub-samples based on the participants' teaching experience. The division of the five teaching categories was based on the relevant literature on teachers' career and professional development (see Berliner, 2005, Day et al., 2006). The first category, student teacher contained those participants who had not yet had any experience as a teacher outside of their training experience. The second group was named novice teacher for those who had been teaching for 1 to 3 years. Competent teacher who had 4-8 years of teaching experience. According to the literature, obtaining 
a high level of teacher competences requires at least 7-9 years. Therefore, the expert teacher category contained those who had at least 9 years of teaching experience. The Berliner's allocation for this section would end here but I was interested in whether there were differences with teachers who had many more years of teaching experience. So one additional category was created, the so called master teacher for those with more than 16 years' experience. Comparative studies were well supported by the fact that the 159 participants presented in approximately the same number of elements in each of the five sub-samples.

\begin{tabular}{|c|c|c|c|c|c|c|}
\hline \multirow[b]{2}{*}{ 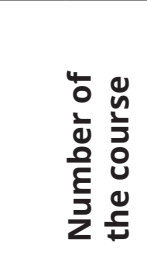 } & \multicolumn{5}{|c|}{ Participants' tecahing experience } & \multirow[b]{2}{*}{ 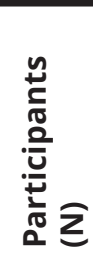 } \\
\hline & 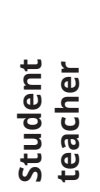 & 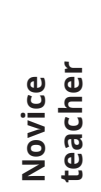 & 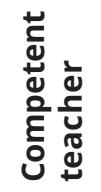 & 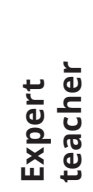 & 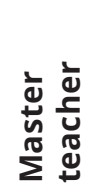 & \\
\hline 1 & 3 & 3 & 5 & 5 & 4 & 20 \\
\hline 2 & 4 & 3 & 4 & 3 & 7 & 21 \\
\hline 3 & 4 & 1 & 3 & 2 & 4 & 14 \\
\hline 4 & 5 & 5 & 5 & 0 & 0 & 15 \\
\hline 5 & 5 & 2 & 1 & 4 & 2 & 14 \\
\hline 6 & 5 & 5 & 1 & 1 & 2 & 14 \\
\hline 7 & 1 & 1 & 2 & 4 & 8 & 16 \\
\hline 8 & 3 & 5 & 4 & 4 & 1 & 17 \\
\hline 9 & 3 & 3 & 4 & 4 & 1 & 15 \\
\hline 10 & 2 & 5 & 1 & 3 & 2 & 13 \\
\hline Sum. & 35 & 33 & 30 & 30 & 31 & 159 \\
\hline
\end{tabular}

4. table: The sample by teaching experiences $(\mathrm{N}=159)$

\section{Results}

The results of the evaluation phase of the research are presented according to the following criteria:

1. The participants' opinions and attitudes regarding the general features (structure, content, usefulness) of the Training Programme

2. The participants' opinions and experiences regarding the effect of the Training Programme

3. Variable analysis regarding teaching experiences 


\subsection{The participants' opinions and attitudes regarding the general features (structure, content, usefulness) of the Training Programme}

General curricular features of the Training Programme were examined by openended questions and Likert-scales. Regarding the open questions the following statements could be made. Mentioning only one word about the whole programme (Open-ended question: If I need to characterize the Training Programme by one word ...) five category were created of the participants' answers ( $N=156)$ : a) words concerning the effect of the training ("useful", "motivating", "effective"); b) words concerning the content of the training ("problem-solving", "possibilities", "cases", information"); c) words concerning the type of the training ("practical", "interactive", "interesting"); d) words concerning the assessment of the training ("good", "perfect", "successful"); e) other answers ("happiness"). About the frequency of the answers it could be said that $37 \%$ of the teachers used positive words for the effectiveness ("useful") of the training, and $36 \%$ of them referred to the practical side of the training ("interactive"). Similarly, the most positive aspect of the programme (Openended question: I liked most in the training...) was the practicality (27\%), and the case analysis possibility (25\%) beside new methods, many point of views, self-awareness, group works according to the answers. Negative observations were only made in regards to the circumstances of the seminars (the timing and the condition) but the features of the educational programme were not criticized.

These findings were supported by skating questions. The answers of the questions addressed the aim, the structure and the content of the programme, and were between 4 and 5 on a five-degree scale. The fact that somebody was a "case-bringer" during the small groups activities influenced these results in a positive way (the practical nature of the course: $r=0.381, p<.001$; the content usefulness: $r=0.286, p=0.001$ ). The participants were also satisfied with the learnt thinking techniques most of these were new for the teachers. The correlations $(r=0.619-r=0.768 ; p<.001)$ showed that those who liked one technique intend to try it in their school practice too.

\subsection{The participants' opinions and experiences concerning the main impact of the Training Programme}

According to the scaled answers $(\mathrm{N}=159)$ the Training Programme resulted in a positive change to certain cognitive areas. On a five-degree scale the improvement in problem solving methods $(\mathrm{M}=4.7, \mathrm{SD}=.589)$ and knowledge $(M=4.63, S D=.669)$ got the highest average value. The participants felt that this knowledge can be utilized both theoretically and practically $(M=4.7, S D=.539)$ in the pedagogical practice. The least popular components by the participants were the integration of the pedagogical and psychological knowledge $(M=4.01$, $\mathrm{SD}=.906)$, and the coordination of the theory and the practice $(M=4.22, S D=.920)$ although the values were above 4 in both cases. The judgment of these variables was influenced by whether the participant was the owner of the analysed situation or they had been in a similar situation to the analysed one $(r=0.333, p<.001)$. 
There were unanimous positive opinions related to the impact of the course examined by open question (Open-ended question: By the effect the course...). The answers were categorized into ten small groups that were put into five bigger groups: a) reflections on the application of techniques ("I learnt new techniques", "I will use the methods for my classroom problems"); b) reflections on the analysed situations ("I see more possible solution for school problems"); c) reflections on some changes of own cognitive process ("I can see behind the problem situation"; "My thinking get structured concerning problem solving process"); d) reflections on personality development ("I had more routine in problem solving"; "I get brave"); e) reflections on rethinking own teaching practice ("I will change my teaching strategy"; ( will change my lesson-planning process"). The highest part of the feedback focused on the application of methods and techniques (30\%), but the measure of the answers were also high related to the analysed situations (23\%) and changes in the participants' own cognitive processes (23\%). (5. table).

1. reflections on the application of techniques: $29,6 \%$

- learning new techniques (5,5\%)

- absorbing new techniques into teaching practice $(24,1 \%)$

2. reflections on the analysed situations: $23,4 \%$

- exemplariness of concrete cases and solutions (11\%)

- old problems in new light $(8,3 \%)$

- meeting different kinds of views $(4,1 \%)$

3. reflections on some changes of own cognitive process: $23,2 \%$

- thinking more about learnt information $(3,4 \%)$

- improving system thinking $(1,2 \%)$

- more conscious approach to the future problems $(18,6 \%)$

4. reflections on personality development: $16,6 \%$

- increasing self-confidence $(6,9 \%)$

- getting more routine, better problem solving $(9,7 \%)$

5. reflections on rethinking own teaching practice: $4,8 \%$

5. table: The main and the sub categories of participans' opinions related to the impact of the course examined by open question (relative frequency, $\mathrm{N}=159$ )

\subsection{Variable analysis regarding teaching experiences}

The main features of the Training Programme was rated uniformly positive by the participants with an average value of between 4 and 5 on a five-degree scale. Focusing on the differences of the opinions according to participants' teaching experience only some cases showed variance. As far as the scaled questions are concerned the agreement of the usefulness of the training content varied slightly differences among subgroups of teachers. Novice teachers tended to give a bit lower scores than experienced ones but the correlation between subgroups and agreement was weak $(r=0.235, p<.01)$ because of the standard deviations. Similar data $(r=217, p<.01)$ was found in the case of rethinking problem solving as a cognitive process. Novice teachers also seemed a little sceptical $(M=4.41$, $\mathrm{SD}=.837$ ) about the usefulness of knowledge of problem solving when compared the other subgroups which gave higher scores. Concerning the participants' 
teaching experiences and their opinions more significant differences were found in their answers to open-ended questions.

Touching the most attractive feature of the Training Programme (Openended question: "I liked most in the training...") most of the student teacher highlighted the interactive nature of the course (26\%). The novice teacher group appraised the analysis of the real-world situations and the concrete solutions (33\%). The dominant answers were on the practical knowledge in the reflection of the competent teachers (23\%), the expert teachers (38\%) and master teachers (45\%).

Speaking about the impact of the Training Programme (Open-ended question: "By the effect the course...") the following results were reported. Analysing the data according to subgroups it can be said that the majority of competent teachers (28\%) highlighted the more conscious approach to the future problems in their answers, while the highest number of the novice teacher groups referred to the exemplariness of concrete cases and solutions (26\%). The dominant part of the answers referred to applying techniques in the other subgroups (the $25 \%$ of student teacher, the $27 \%$ of expert teacher, and the $32 \%$ of master teacher). (6. table)

\begin{tabular}{|c|c|c|c|c|c|}
\hline Answer categories & 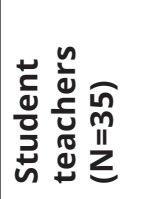 & 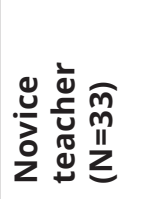 & 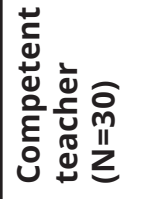 & 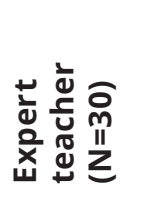 & 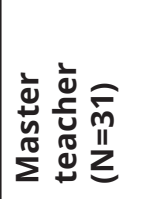 \\
\hline $\begin{array}{l}\text { Getting more routine } \\
\text { for problem solving }\end{array}$ & $15,6 \%$ & $9,7 \%$ & $6,9 \%$ & $0,0 \%$ & $13,8 \%$ \\
\hline $\begin{array}{l}\text { Learning new } \\
\text { techniques }\end{array}$ & $12,5 \%$ & $6,5 \%$ & $6,9 \%$ & $0,0 \%$ & $0,0 \%$ \\
\hline $\begin{array}{l}\text { Meeting different kind } \\
\text { of views }\end{array}$ & $3,1 \%$ & $9,7 \%$ & $3,4 \%$ & $0,0 \%$ & $3,4 \%$ \\
\hline $\begin{array}{l}\text { Rethinking own } \\
\text { teaching practice }\end{array}$ & $3,1 \%$ & $6,5 \%$ & $3,4 \%$ & $0,0 \%$ & $10,3 \%$ \\
\hline $\begin{array}{l}\text { More conscious } \\
\text { attention to new } \\
\text { problems }\end{array}$ & $18,8 \%$ & $12,9 \%$ & $27,6 \%$ & $15,4 \%$ & $17,2 \%$ \\
\hline $\begin{array}{l}\text { Improving of system } \\
\text { thinking }\end{array}$ & $0,0 \%$ & $0,0 \%$ & $0,0 \%$ & $0,0 \%$ & $6,9 \%$ \\
\hline $\begin{array}{l}\text { Increasing } \\
\text { self-confidence }\end{array}$ & $9,4 \%$ & $3,2 \%$ & $10,3 \%$ & $7,7 \%$ & $3,4 \%$ \\
\hline $\begin{array}{l}\text { Old problems in new } \\
\text { light }\end{array}$ & $3,1 \%$ & $3,2 \%$ & $6,9 \%$ & $23,1 \%$ & $10,3 \%$ \\
\hline $\begin{array}{l}\text { Absorbing new } \\
\text { techniques into } \\
\text { practice }\end{array}$ & $25,0 \%$ & $16,1 \%$ & $17,2 \%$ & $26,9 \%$ & $31,0 \%$ \\
\hline
\end{tabular}




\begin{tabular}{|c|c|c|c|c|c|}
\hline Answer categories & 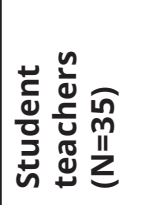 & 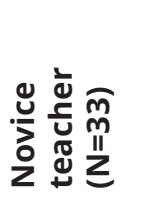 & 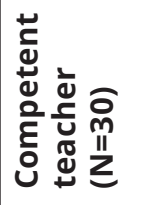 & 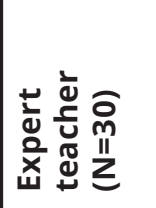 & 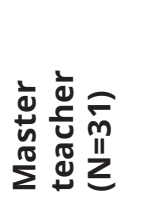 \\
\hline $\begin{array}{l}\text { Exemplariness of } \\
\text { specific cases }\end{array}$ & $0,0 \%$ & $25,8 \%$ & $10,3 \%$ & $15,4 \%$ & $3,4 \%$ \\
\hline $\begin{array}{l}\text { Thinking about learnt } \\
\text { information }\end{array}$ & $6,3 \%$ & $6,5 \%$ & $3,4 \%$ & $7,7 \%$ & $0,0 \%$ \\
\hline Other answers & $3,1 \%$ & $0,0 \%$ & $3,4 \%$ & $3,8 \%$ & $0,0 \%$ \\
\hline Total & $100,0 \%$ & $100,0 \%$ & $100,0 \%$ & $100,0 \%$ & $100,0 \%$ \\
\hline
\end{tabular}

6. table: The proportions of teachers answers concerning the main impact of the Training Programme by subgroups (relative frequency, $\mathrm{N}=159$ )

Analysing the data by answer categories, master teachers (10,3\%) mentioned that the most important impact of the training was rethinking their own teaching practice. They were the only ones $(6,9 \%)$ that noticed changes in their system thinking.

Many participants for every subgroups mentioned the adoption of the new techniques into their teaching practice but most of them were expert teachers $(27 \%)$ and master teachers (31\%).

The highest rate of the participants who mentioned more conscious approach to new problems were the competent teachers (28\%) (3. figure).

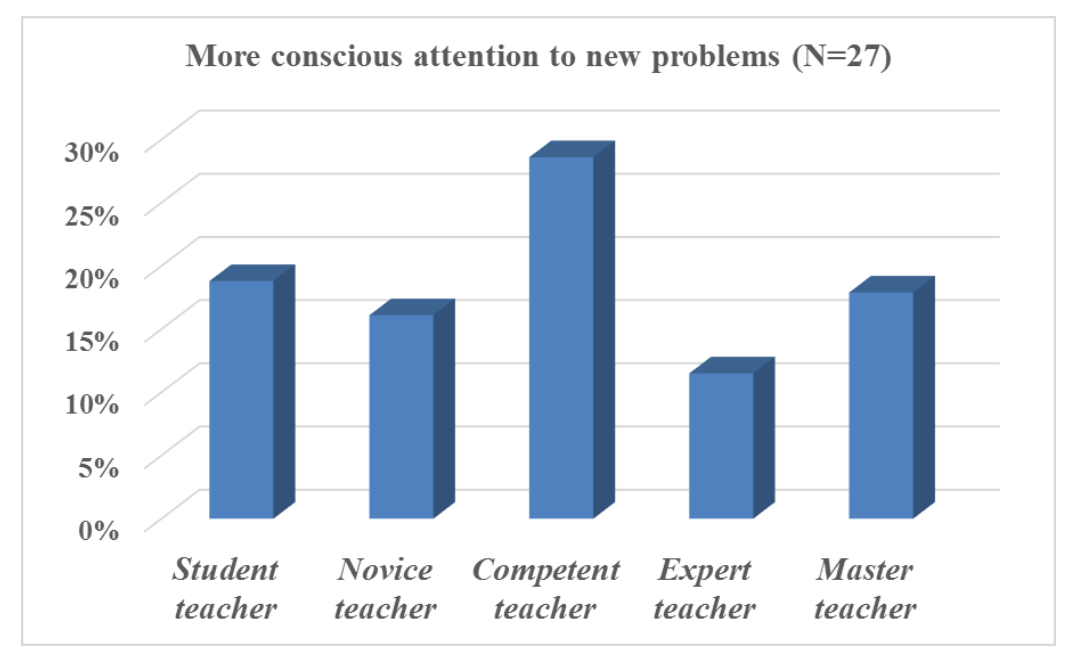

3. figure The proportions of teachers' answers that mentioned more conscious attention to new problems as the most important impact of the training (relative frequency, $\mathrm{N}=27$ ) 
Expert teachers were also those who most appreciated (23\%) that the old problems got new light in the training (4. figure).

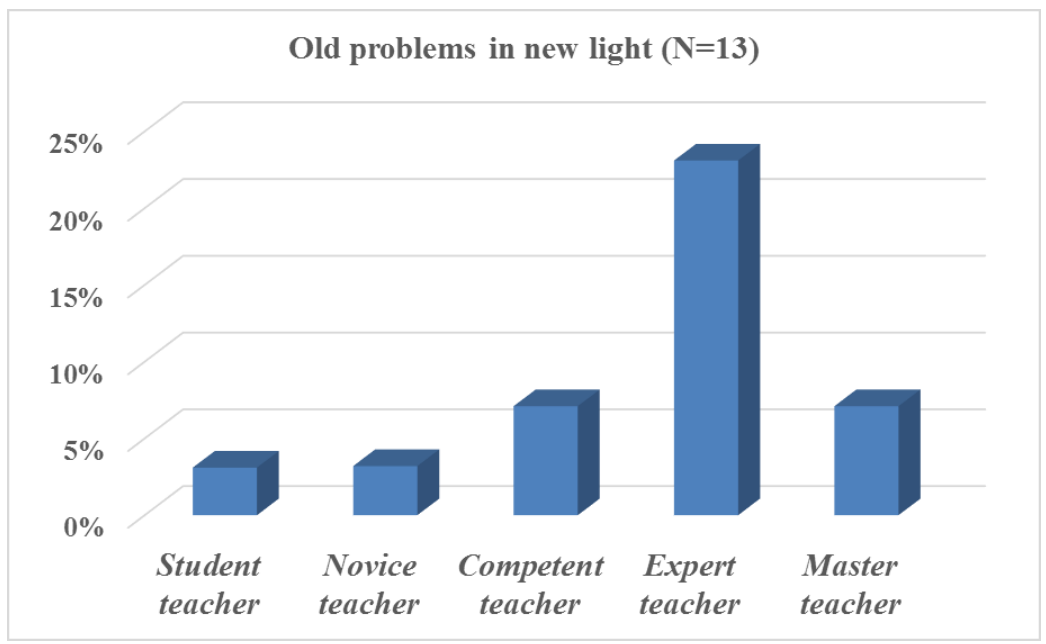

4. figure The proportions of teachers' answers that mentioned old problems in new light like the most important impact of the training (relative frequency, $\mathrm{N}=13$ )

It was the novice teachers $(9,7 \%)$ who found the most usefulness in different kinds of views during the training. This subgroup also appreciated the exemplariness of concrete cases and solutions as the most important impact of the course. (25,8\%). (5. figure).

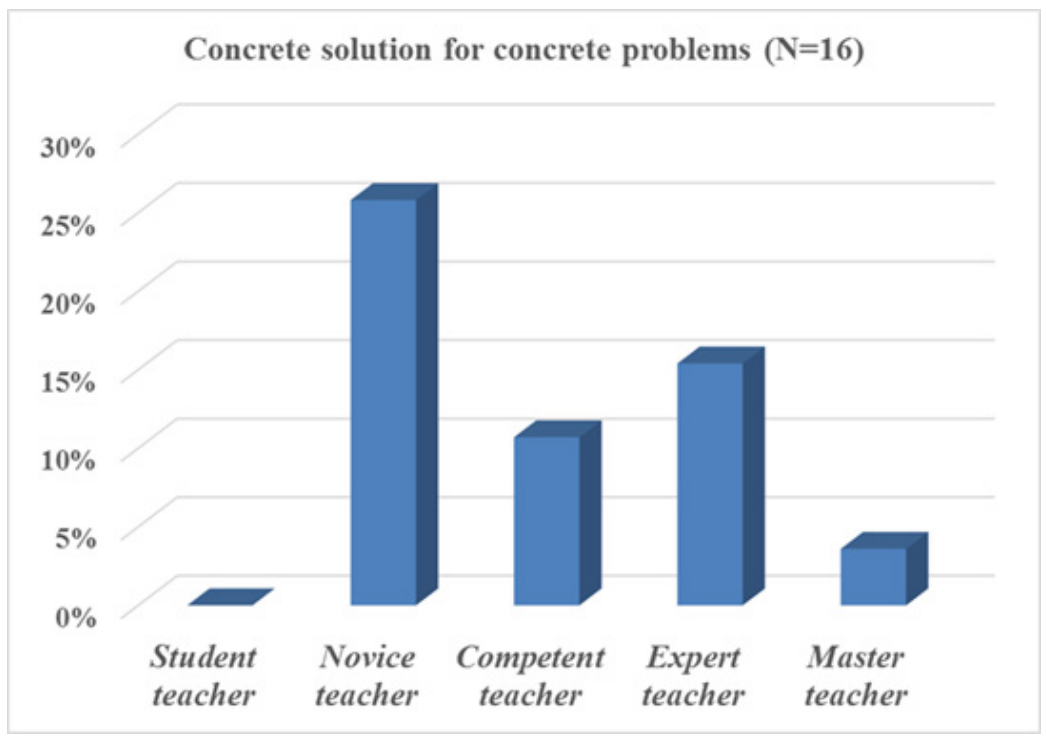

5. figure The proportions of teachers' answers that mentioned the exemplariness of specific cases as the most important impact of the training (relative frequency, $\mathrm{N}=16$ ) 
The new knowledge about the problem solving techniques was highlighted by student teachers (12,5\%). Also student teachers (16\%) felt the most that they gained more routine concerning problem solving process, but this opinion was also popular among master teachers (14\%).

\section{Discussion}

According to the summative evaluation of the developed Training Programme teachers were satisfied with the main features of it. All teachers were pleased with the learnt problem solving thinking techniques and they expressed their commitment to adopting them into their teaching practice. However, in analysing the opinions and attitudes regarding the training, some differences were revealed between novice and expert teachers' thinking.

Student teachers seemed to be the happiest out of all the participants in learning new problem solving techniques. They also expressed their commitment in high rate to adopting these new techniques into practice. Novice teachers (with 1-3 years teaching experience) seemed to concentrate most on the exemplariness of specific cases and situations that were analysed during the courses. Competent teachers (with 4-8 years teaching experience) were most marked in their giving more conscious attention to the new problems as a result of the Training Programme. Expert teachers (with 8-15 years teaching experience) gave most the feedback about seeing old problems in new light as the main impact of the programme. Master teachers (with more than 16 years' experience) were the most committed to putting new techniques into the practice. They also reflected rethinking own teaching practice at the highest rate. They were the only ones who mentioned the improvement in their system thinking as a result of the Training Programme.

Summarizing the results novice teachers on one hand seemed to be the most sceptical group regarding the usefulness of content-independent thinking techniques for problem solving. On the other hand they appreciated the most the real-world examples with concrete solutions and best working scripts. The explanation of this result relates to the cognitive structures of new teachers. New teachers' cognitive structures and schematic thinking of school situations are less developed so they tend to stop at the surface level during the perception. Their solutions processes often focus on the aim and the most perceptible part of the phenomena. That is why they have high demand for concrete solutions, tips or scripts that they can put into their own situations. They often do not notice the different causes and features behind the situations. That can be the reasons that they show the least appreciation of all the participants in thinking of techniques that help to uncover what behind the surface of problems.

Experienced teachers cognitive structures were more sophisticated as they store numerous schema and examples of class situations. Their solutions processes focused on the information and causes so they were able to choose 
solutions according to the deep features of situations. The sematic thinking and particular routine of reactions for the constantly recurring situations can work routine expertise out. This kind of expertise, however, may not be able to answer completely new challenges as well as adaptive expertise can. Expert and Master teachers in this study had supposedly routine expertise. That could be the reason they appreciate most the thinking techniques learnt in the training as it could help them to step out from old schemas and provide totally different views of situations and provide possible solutions.

\section{Conclusion}

In this study the summative results of a design-based research was presented related to the shortened, eight-hours long version of the Training Programme for Teachers' Professional Development on Problem Solving (Orgoványi-Gajdos, 2016). The sample consisted of 159 participants that had been divided into subgroups by the participants' teaching experience (years) following Berliner's categories (2005).

According to the participants' reflections the Training Programme with thinking techniques can provide useful mental framework for both student teachers and expert ones. It seems that missing routine and routine expertise could also lead to less sophisticated problem solving processes.

As far as student teachers' practical preparation is concerned the Programme could be a useful supplement by providing them with possibilities of deeper observation of classroom events; viewing school situations as a coherent process; analysing the background of pedagogical problems; connecting the theoretical and practical elements of teaching; integrating their different psychological, pedagogical and content knowledge. The Programme could also support a new teachers' induction process, because it helps novices to absorb pedagogic situations into a system; to move from short-term to long-term thinking; to be able to develop their own solution strategies; to change their initial teachercentred approach into a more student-centred approach. However, they do may not understand the role of thinking models because they are not aware of the details of the situation and they may perceive just the surface of the context. So, the thinking frames need to be presented with many real teaching examples and case studies. The Programme encourages experienced teachers to become adaptive experts as it gives them the possibility to restructure former frames and schemas as well as review the usefulness of old routines; to promote conceptual changes and inventions. 
Judit, Orgoványi-Gajdos

\section{BIBLIOGRAPHY}

Berliner, D. C. (1988). The Development of Expertise in Pedagogy. American Association of Colleges for Teacher Education. New Orleans, La.

Berliner, D. C. (2004). Describing the Behaviour and Documenting the Accomplishments of Expert Teachers. Bulletin of Science, Technology \& Society, 24(3), 200-212.

Bono, E. de (1996). Teach Yourself to Think. Penguin Books Ltd.

Borko, H., \& Livingston, C. (1989). Cognition and improvisation: Differences in mathematics instruction by expert and novice teachers. American Educational Research Journal, 26(4), 473-498

Bransford, J. D., Brown, A. L., Cocking, R. R. edt. (2000): How People Learn: Brain, Mind, Experience, and School. Washington, DC: National Academy Press.

Brown S. A. \& McIntyre D. (1993): Making sense of teaching. Developing teachers and teaching. Open University Press

Calderhead, J. (1993). The contribution of research on teachers' thinking to the professional development of teachers, in: Day, C., Calderhead, J. and Denicolo, P. eds., Research on Teacher Thinking: Understanding Professional Development, London, Falmer Press.

Carter, K. (1990). Teachers' knowledge and learning to teach. In W. R. Houston (Ed.), Handbook of research on teacher education (pp. 291-310). New York: Macmillan.

Carter, K. \& Doyle, W. (1987): Teachers' knowledge structures and comprehension processes. In: J. Calderhead (Ed.), Exploring teachers' thinking. London: Holt, Rinehart and Winston.

Clark, C. M. \& Peterson, P. L. (1986): Teachers' thought processes. In M. C. Wittrock (Ed.), Handbook of research on teaching (pp. 255-296). New York: Macmillan

Copeland, W. D., Birmingham, C., De La Cruz, E., \& Lewin B. (1993): The reflective practitioner in teaching: Toward a research agenda. Teaching and Teacher Education, 9, 347-359.

Creswell, J. W., \& Plano Clark, V. L. (2011): Designing and conducting mixed methods research (2nd ed.). Thousand Oaks, CA: Sage Publications, Inc.

Darling-Hammond \& J. Bransford eds. (2005): Preparing teachers for a changing world: What teachers should learn and be able to do. San Francisco: Jossey-Bass.

Day, C., Stobart, G., Sammons, P. c Kington, A. (2006). Variations in the Work, Lives of Teachers: Relative and Relational Effectiveness. Teachers and Teaching: Theory and Practice, 12(2),169-192

Doyle, W. (1979). Making managerial decisions in classrooms. In D.L. Duke (Ed.), Classroom Management (78th Yearbook of the National Society for the Study of Education (pp. 42-74). Chicago: University of Chicago Press.

Eberle, R. (1971): SCAMPER games for imagination development. New York: DOK Publications.

Eysenck, M. \& Keane M. T (2010): Cognitive Psychology. A Student's Handbook. Psychology Press. 
Glenn, J. C. (1972). Futurizing Teaching vs Futures Course, Social Science Record, Social Science Record, 9(3), 26-29

Hatano, G., \& Inagaki, K. (1986). Two courses of expertise. In H. Stevenson, J. Azuma \& K. Hakuta (Eds.), Child development and education in Japan (pp. 262-272). New York, NY: W. H. Freeman \& Co.

Hogen, T. \& Rabinowitz, M. (2009). Teacher expertise and the development of a problem representation. Educational Psychology 29(2), 153-169.

Hogan, T. M., Rabinowitz, M, \& Craven, J. (2003). Problem representation in teaching: Inferences from research of expert and novice teachers, Educational Psychologist, 38, 235-247.

Hogue, R. J. (2013): Epistemological Foundations of Design-Based Research. Oral presentation at CSSE/CERA Canadian Society for the Study of Education/ Canadian Educational Researchers' Association annual conference. Victoria, British Columbia.

Ishikawa, K. (1982): Guide to Quality Control (Second Revised English Edition), Tokyo: Asian Productivity Organization.

Kagan, D. M. (1992). Professional growth among preservice and beginning teachers. Review of Educational Research, 62(2), 129-169.

Killion, J., \& Todnem, G. (1991). A process for personal theory building. Educational Leadership, 48(6), 14-16

Korthagen, F. A. (1993). Two modes of reflection. Teaching and Teacher Education, 9(3), 317-326.

Krippendorff, Klaus (2004): Content Analysis: An Introduction to Its Methodology. California

Lampert, M. (2001): Teaching Problems and the Problems in Teaching. New Haven, CT: Yale.

Lewin, K. (1947) Group Decision and Social Change. In: Newcomb, T. and Hartley, E., Eds., Readings in Social Psychology (pp. 197-211). Holt, Rinehart \& Winston, New York,

Melnick, S. A., \& Meister, D. G. (2008). A Comparison of Beginning and Experienced Teachers' Concerns. Educational Research Quarterly, 31(3), 39-56.

Munby, H., Russel, T., \& Martin, A.K. (2001). Teachers' knowledge and how it develops. In V. Richardson (Ed.), Handbook of Research on Teaching (pp. 877-904). Washington: AERA

OECD (2005): Teachers Matter - Attracting, Developing and Retaining Effective Teachers, OECD Publishing.

Orgoványi-Gajdos, J. (2016): Teachers' Professional Development on Problem Solving. Theory and Practice for Teachers and Teacher Educators. Sense Publishers. Rotterdam.

Peterson, P. L. \& Comeaux, M. A. (1987). Teachers' schemata for class- room events: The mental scaffolding of teachers' thinking during classroom instruction. Teaching and Teacher Education, 3(4), 319-331.

Shavelson, R. J. (1973). What Is The Basic Teaching Skill? Journal of Teacher Education, 24(2), 144-151. 
Tague, N. R. (2005): The Quality Toolbox (Vol. 600). Milwaukee, WI: ASQ Quality Press.

Tann S. (1994). Supporting the Student Teacher in the Classroom In.: Margaret Wilkin and Derek Sankey ed.: Collaboration and Transition in Initial Teacher Training (pp. 94-106).

Tsui, A. (2009). Teaching Expertise: Approaches, Perspectives and Characterizations. In. A. Burns \& J. C. Richards (Eds.), Cambridge Guide to Second Language Teacher Education (pp. 190-197). Cambridge, Cambridge University Press.

Van den Akker, J. (2007). Curriculum Design Research. In. Plomp T. and Nieveen N. (ed.) (2007): An Introduction to Educational Design Research (pp. 37-53). SLO Netherlands institute for curriculum development

Van Velzen, C., Volman, M., Brekelmans, M., \& White, S. (2012). Guided workbased learning: Sharing practical teaching knowledge with student teachers. Teaching and Teacher Education, 28(2), 229-239.

Veenman, S., (1984): Perceived problems of beginning teachers. Review of Educational Research 54, 143-178

Westerman, D. A. (1991). Expert and Novice Teacher Decision Making. Journal of Teacher Education, 42(4), 292-305. 